\title{
KEMAMPUAN PREDASI TUNGAU PREDATOR AMBLYSEIUS SP. RESISTEN TEMPERATUR TERHADAP TETRANYCHUS URTICAE
}

\author{
Bambang Heru Budianto \& Edi Basuki \\ Laboratorium Entomologi-Parasitologi, Fakultas Biologi, Universitas Jenderal Soedirman \\ E-mail : bhbudianto@gmail.com
}

\begin{abstract}
The predation ability of temperature resistant Amblyseius sp. to Tetranychus urticae. Global warming and climate changes have caused great mortality of the predatory mites Amblyseius sp. that disrupts the natural control of Tetranychus urticae. In contrast, the low humidity and high temperature led to an increase in the population of T. urticae. The purposes of this study were to determine the effect of temperature on population of the predatory mites Amblyseius sp. and to determine the predation ability of temperature resistant Amblyseius sp. on T. urticae. The selection of Amblyseius sp. was conducted at temperatures of $15,20,25,30$ and $35{ }^{\circ} \mathrm{C}$. The parental predatory mite Amblyseius sp., and subsequent descendants were exposed to the temperature range until the values of the $\mathrm{LT}_{50}$ fiducial limits (FL) of a certain generation did not overlap with that of the previous one. The effectiveness of Amblyseius sp. predation ability was studied using an experimental method i.e. completely randomized design with four treatments and ten replications . For this purpose, each stage of T. urticae, i.e. egg, larvae, nymph and adult was set as treatment and was given to any type of temperature resistant predatory mite Amblyseius sp. The results showed that by using the temperature gradient, we managed to select temperature-resistant individuals from their population. These individuals formed a population that was resistant to temperature of up to $33.3^{\circ} \mathrm{C}$ without losing their predatory capacity, especially on the egg stage of T.urticae.
\end{abstract}

Key words: predatory mite Amblyseius sp., selection of temperature resistant Amblyseius sp., effectiveness of predation abilities, Tetranychus urticae

\begin{abstract}
ABSTRAK
Kemampuan predasi populasi tungau predator Amblyseius sp. resisten temperatur terhadap Tetranychus urticae. Pemanasan global dan perubahan iklim telah menyebabkan mortalitas yang besar terhadap tungau predator Amblyseius sp. sehingga mengganggu pengendalian alamiah hama Tetranychus urticae. Sebaliknya, kelembaban udara yang rendah dan suhu yang tinggi menyebabkan terjadinya peningkatan populasi tungau T. urticae. Tujuan penelitian ini adalah mengetahui pengaruh temperatur terhadap populasi tungau predator Amblyseius sp. dan menentukan efektivitas predasi tungau predator Amblyseius sp. resisten temperatur terhadap T. urticae. Seleksi tungau predator Amblyseius sp. terhadap temperatur dilakukan terhadap 300 individu pada temperatur 15,20,25,30 dan $35^{\circ} \mathrm{C}$. Kisaran temperatur didedahkan pada induk tungau predator Amblyseius sp. dan keturunan-keturunan berikutnya, sampai nilai fiducial limit $(\mathrm{FL}) \mathrm{LT}_{50}$ tidak saling lingkup pada keturunan tertentu dibanding keturunan sebelumnya. Efektivitas predasi Amblyseius sp. Dilakukan dengan menggunakan metode eksperimental: rancangan acak lengkap. Perlakuan berupa stadia telur, larva, nimfa dan dewasa T. urticae yang diberikan pada setiap jenis tungau predator Amblyseius sp. resisten temperatur yang dipergunakan. Hasil penelitian menunjukkan bahwa temperatur mampu menyeleksi individu-individu penyusun populasi tungau predator Amblyseius sp. yang rentan temperatur menjadi populasi yang resisten terhadap temperatur hingga $33,3^{\circ} \mathrm{C}$. Perubahan menjadi populasi tungau predator Amblyseius sp. yang resisten temperatur tidak mengubah efektivitas predasi yang tetap tinggi terhadap stadium telur $T$. urticae dibandingkan stadium T. urticae yang lain.
\end{abstract}

Kata kunci : tungau predator Amblyseius sp., seleksi Amblyseius sp. resisten temperatur, efektivitas kemampuan predasi, Tetranychus urticae

\section{PENDAHULUAN}

Tetranychus urticae merupakan tungau hama polifag yang menyerang berbagai jenis tanaman, baik tanaman hias maupun sayuran yang ditanam di rumah kaca dan di luar rumah kaca, termasuk tanaman ubi kayu. Tungau ini mengalami empat stadia metamorfosis, 
yaitu telur, larva, nimfa dan dewasa (Bakker et al., 1993).

Tungau T. urticae menyebar dari tepi daun ke semua bagian daun sehingga warna daun menjadi kemerah-merahan, coklat atau seperti karat. Tungau ini membentuk jaring pada daun dan antar daun. Jaring ini menjadi tempat peletakan telur betina hingga menetas menjadi stadium pradewasa. Serangan yang parah dari T. urticae dapat menyebabkan kerontokan daun atau defoliasi (Bakker, 1994).

Selain disebabkan oleh serangan tungau hama $T$. urticae, perubahan iklim berupa pemanasan global dan perubahan cuaca sebagaimana yang berlangsung sepanjang tahun ini di hampir seluruh wilayah Indonesia, telah menyebabkan potensi kerugian ekonomi hasil panen ubi kayu meningkat. Pemanasan global dan perubahan iklim selain menurunkan aktivitas fotosintesis tanaman ubi kayu, juga telah menyebabkan mortalitas tungau predator yang mengendalikan tungau hama secara alamiah termasuk terhadap T. urticae.

Skirvin \& Fenlon (2003) mengemukakan bahwa telah terjadi mortalitas yang besar pada jenis-jenis tungau predator famili Phytoseiidae akibat pemanasan global dan perubahan iklim sehingga biodiversitas tungau famili ini menurun dan mengganggu fungsi pengendalian hayati alamiahnya (Skirvin \& Fenlon, 2003). Hanna et al. (2005) telah mencatat bahwa pengendalian alamiah berbagai tungau predator famili Phytoseiidae yaitu Phytoseius amba, Amblyseius aeralis dan Euseius concordis tidak mampu berlangsung dengan sempurna akibat pemanasan global dan perubahan iklim. Di sisi lain, kondisi tersebut masih dapat ditoleransi oleh populasi tungau hama termasuk T. urticae karena tungau hama ini lebih tahan terhadap perubahan iklim termasuk pemanasan global dibandingkan tungau predatornya. Crooker (1985) dan Zundel et al. (2009) mengemukakan bahwa kondisi lingkungan seperti kelembaban udara yang rendah dan suhu yang tinggi akan menyebabkan terjadinya peningkatan populasi tungau hama dan menurunkan biodiversitas tungau predator. Luedeling $e t$ al. (2011) mengemukakan bahwa perubahan iklim berupa pemanasan global telah meningkatkan jumlah generasi berbagai macam jenis tungau hama termasuk Tetranychidae di Kalifornia yang mencapai 14 sampai 20 dari semula 9 sampai 14 generasi.

Meningkatnya jumlah generasi tungau hama Tetranychus sp. dan menurunnya populasi dan biodiversitas jenis tungau predator famili Phytoseiidae menunjukkan tingginya kemampuan resistensi tungau hama namun sebaliknya rendahnya daya adaptasi tungau predator terhadap pemanasan global dan perubahan cuaca. Tsoukanas et al. (2006) mengemukakan bahwa salah satu syarat menjadi tungau predator yang efektif adalah mempunyai kemampuan mentolerir temperatur, selain ketergantungan terhadap mangsa, yang tinggi, dan dengan daya reproduksi yang tinggi. Salah satu tungau predator dari famili Phytoseiidae yang memiliki kapasitas berburu mangsa yang tinggi dan memiliki preferensi terhadap tungau Tetranychus sp. adalah Amblyseius sp.

Ukuran tubuh Amblyseius sp. kurang lebih 0,5 mm dengan abdomen lebih membulat, memiliki 4 seta di bagian posterior, yang terdiri atas 2 seta panjang dan 2 seta pendek. Di dalam ventrianal shield terdapat 8 seta dan 3 seta yang lain terletak pada bagian samping atas dan bawah anus, sedangkan di atas ventrianal shield tepatnya di ujung samping atas dijumpai 2 seta. Panjang tubuh keseluruhan mencapai rata-rata 525,36 $\mu$. Panjang rata-rata seta yang terletak di bagian ujung posterior mencapai 372,4 $\mu$ (seta pendek) dan $441 \mu$ (seta panjang) (Denmark \& Muma, 1989).

Telah dijelaskan sebelumnya bahwa tungau predator Amblyseius sp. memiliki kapasitas berburu yang tinggi dan memiliki preferensi terhadap tungau Tetranychus sp. Meskipun demikian, belum diperoleh informasi kemampuan toleransinya terhadap temperatur serta efektivitas kemampuan predasinya setelah resisten temperatur. Sebaliknya, kemampuan mentoleransi berbagai jenis tungau hama Tetranychus sp. terhadap kisaran temperatur telah dibuktikan oleh beberapa peneliti (Skirvin \& Fenlon, 2003; Gotoh et al., 2004; Domingos et al., 2010; Xia et al., 2012).

Kemampuan berbagai jenis tungau predator famili Phytoseiidae termasuk Amblyseius sp. dalam mentolerir temperatur merupakan langkah utama menuju seleksi tingkat resistensinya. Seleksi resistensi tungau predator pada dasarnya merupakan upaya pemilihan sifat-sifat resisten dari individu-individu dalam populasi (Mochizuki, 1994; Xia et al., 2012). Sifat resisten tersebut ditunjukkan oleh kemampuan bertahan hidup dan berkembang, meskipun terjadi pemanasan global.

Kemampuan bertahan hidup dan berkembang yang berulang pada setiap generasi akibat akibat pemanasan global, dapat terjadi oleh karena menurunnya kompetisi intraspesies akibat matinya individu yang rentan (Knulle, 1991; Lee \& Gillespie, 2011). Kematian individu yang rentan, yang menjadi komponen penyusun utama populasi, akan menyebabkan terjadinya pergeseran komponen penyusun utama populasi tersebut. Cepat atau lambatnya perubahan komposisi individuindividu menjadi resisten temperatur, sangat ditentukan oleh perbedaan tanggap resistensinya terhadap kenaikan temperatur itu sendiri (Bakker \& Jacas, 1995; Lee \& Gillespie, 2011). 
Seleksi tungau predator Amblyseius sp. terhadap temperatur diduga dapat mempengaruhi efektivitas predasi tungau predator. Efektivitas predasi yang dimaksud di sini adalah banyaknya mangsa yang dimangsa oleh setiap individu predator selama satuan waktu tertentu. Perubahan temperatur lingkungan terhadap tungau predator diduga dapat menyebabkan perubahan perilakunya sebagai reaksi adaptif terhadap kenaikan temperatur melalui peningkatan laju predasi sehingga mengurangi laju kematiannya. Perubahan perilaku ini dapat berupa strategi mencari kondisi temperatur lingkungan yang sesuai atau memangsa stadia tertentu dari mangsa yang akan mengurangi kehilangan energinya (Tian et al., 1992, Allen, 2009).

Berdasarkan asumsi-asumsi sebagaimana telah dikemukakan maka tujuan penelitian ini adalah untuk mengetahui pengaruh temperatur terhadap populasi tungau predator Amblyseius sp. dan menentukan efektivitas predasi tungau predator Amblyseius sp. resisten temperatur terhadap $T$. urticae.

\section{METODE PENELITIAN}

Tempat dan Waktu. Percobaan seleksi tungau predator Amblyseius sp. resisten terhadap temperatur dan efektivitas kemampuan predasinya terhadap T. urticae dilaksanakan di laboratorium Entomologi-Parasitologi, Fakultas Biologi, Universitas Jenderal Soedirman, Purwokerto. Penelitian dilaksanakan selama 6 (enam) bulan, yang dimulai pada bulan Maret sampai dengan minggu ketiga bulan Oktober tahun 2012.

\section{Pemeliharaan Tungau Predator Amblyseius sp.} Metode pemeliharaan tungau predator berdasarkan metode Overmeer et al. (1982). Tempat pemeliharaan tungau terdiri dari nampan berisi air dengan busa didalamnya. Di atas busa, diletakkan "black tile" yang seukuran dengan busa, dengan bagian tepinya dialasi kertas tissue tidak berparfum yang tercelup hingga ke air dalam nampan. Pada sepanjang alas kertas tissue dibuat tanggul dari lem "tangle-foot" untuk mencegah predator tidak lari dari wilayah pemeliharaan. Untuk tempat berlindung dan meletakkan telurnya, di bagian tengah "black tile" diletakkan sedikit kapas yang ditutup dengan penutup plastik berlekuk. Untuk mendapatkan dan memperbanyak tungau predator Amblyseius sp., sejumlah daun ubi kayu dari 5 tangkai daun terbawah, dipetik dan dimasukkan ke dalam kantong plastik. Di laboratorium, seluruh daun tersebut diperiksa di bawah mikroskop binokuler. Tungau Amblyseius sp. yang diperoleh, dipindah ke tempat pemeliharaan. Jenis pakan yang diberikan dalam masa perbanyakan tungau predator adalah adalah telur $T$. urticae dan polen kembang sepatu (Hibiscus rosa-sinensis) segar. Telur T. urticae diperoleh dengan mengambil langsung dari daun ubi kayu yang dipelihara pada pot-pot di rumah kaca.

Seleksi Tungau Predator Amblyseius sp. Resisten Temperatur. Seleksi dilakukan pada nampan tempat pemeliharaan (rearing) yang masing-masing berisi 300 ekor tungau predator Amblyseius sp. Seleksi dilakukan dengan mendedahkan tungau predator Amblyseius sp. tersebut pada temperatur $15,20,25,30$ dan $35^{\circ} \mathrm{C}$. Kisaran temperatur bertingkat tersebut merupakan awal memperoleh nilai $\mathrm{LT}_{50}$ (Lethal Temperature 50). Kisaran temperatur didedahkan pada induk dan keturunanketurunan berikutnya, sampai nilai fiducial limit (FL) $\mathrm{LT}_{50}$ tidak saling lingkup pada keturunan tertentu dibanding keturunan sebelumnya. Setiap kisaran temperatur yang dicobakan melibatkan 10 individu predator. Setiap perlakuan temperatur diulang sebanyak enam kali. Lama waktu pendedahan terhadap temperatur adalah 12 hari sesuai dengan lama waktu daur hidup tungau predator Amblyseius sp. Tungau predator yang bertahan hidup dipindah ke tempat pemeliharaan yang bebas pestisida, untuk diperbanyak kembali dan kemudian didedahkan lagi sampai nilai FC $\mathrm{LT}_{50}$ tidak saling lingkup antara keturunan tertentu dengan keturunan sebelumnya.

Data yang diperoleh berupa mortalitas populasi tungau predator pada setiap rentang temperatur yang dicobakan dianalisis dengan analisis probit logit. Hasil analisis probit logit berupa nilai FC $\mathrm{LT}_{50}$ setiap generasi tungau predator dan dikatakan tungau predator telah resisten terhadap temperatur apabila nilai tersebut tidak selingkup dengan nilai fiducial limit lethal temperatur 50 generasi sebelumnya. Selain nilai FC, dihitung pula nilai rasio resistensi (RR) yang merupakan perbandingan nilai $\mathrm{LT}_{50}$ suatu generasi dengan nilai $\mathrm{LT}_{50} \mathrm{P}$ (parental $=$ induk). Nilai RR menunjukkan tetapan besaran peningkatan resistensi suatu generasi dibandingkan generasi induk. Tetapan besaran nilai RR yang menunjukkan perkembangan suatu populasi dalam menuju resistensinya dipertegas oleh nilai $\chi^{2}$ dan slope. Berdasarkan nilai $\chi_{\text {hitung }}^{2}$ yang dibandingkan dengan nilai $\chi_{0.05}^{2}$ dapat diketahui tingkat heterogenitas populasi dalam merespons rentang temperatur yang didedahkan dan berdasarkan nilai slopenya dapat diketahui kekuatan tingkatan perubahan populasi menuju resisten. 
Efektivitas Predasi Tungau Predator Amblyseius sp. Resisten Temperatur terhadap T. urticae. Rancangan percobaan yang dipergunakan adalah rancangan acak lengkap, dengan perlakuannya adalah tahap telur, larva, nimfa dan dewasa $T$. urticae yang diberikan pada setiap jenis tungau predator Amblyseius sp. resisten temperatur yang dipergunakan. Setiap perlakuan diulang sebanyak 10 kali. Jumlah tahap telur, larva, nimfa dan dewasa $T$. urticae yang diberikan untuk setiap individu dari setiap jenis tungau predator Amblyseius sp. adalah 6 buah. Seluruh percobaan ini dilakukan pada kelembaban dan temperatur kamar. Dicatat lama waktu mencari, mengenali dan menangani mangsa untuk setiap individu predator. Dicatat pula banyaknya individu setiap tahap yang dipredasi oleh setiap jenis tungau predator Amblyseius sp. dalam 24 jam waktu pengamatan. Data berupa banyaknya individu setiap stadia $T$. urticae yang dipredasi oleh tungau predator Amblyseius sp. resisten temperatur, dianalisis dengan analisis ragam (Anara) pada taraf nyata 5\% dan $1 \%$, yang dilanjutkan dengan uji beda nyata terkecil (BNT) pada taraf nyata yang sama.

\section{HASIL DAN PEMBAHASAN}

Uji pendahuluan pada parental Amblyseius sp. diperoleh LT50/24 jam untuk temperatur sebesar 20,4 ${ }^{\circ} \mathrm{C}$ dengan kisaran temperatur 19,1 sampai $21,6{ }^{\circ} \mathrm{C}$. Populasi induk ini dijadikan sebagai standar nilai rasio resistensi dan dianggap bernilai $1(R R=1)$ dengan asumsi populasi induk merupakan populasi paling rentan terhadap temperatur. Berdasarkan nilai $\chi_{\text {hitung }}^{2}$ populasi induk tungau Amblyseius sp. yang lebih besar dibandingkan nilai $\chi_{0.05}^{2}$ dapat diketahui bahwa komposisi populasi tungau predator Amblyseius sp. masih sangat heterogen, artinya komposisi populasi sebagian besar tersusun oleh kumpulan individu yang rentan terhadap temperatur dibandingkan yang resisten (Tabel 1).

Hasil percobaan pada generasi berikutnya (F1, F2 dan F3) menunjukkan komposisi populasi yang belum berubah yang ditunjukkan oleh nilai fiducial limit yang masih selingkup serta nilai $\chi^{2}$ hitung parental, F1, F2 dan F3 yang masih lebih besar dibandingkan $\chi^{2}$ tabel (Tabel 1). Lebih besarnya nilai $\chi^{2}$ hitung parental, F1, F2 dan F3 dibandingkan nilai $\chi^{2}$ tabel menunjukkan komposisi populasi yang masih didominasi oleh individu-individu dengan fenotipe rentan. Dominasi individu-individu rentan juga dapat dilihat dari nilai slope yang menunjukkan tingkat keterjalan garis yang mencerminkan heterogenitas individu penyusun populasi sebagai responsnya terhadap rentang temperatur yang dicobakan.

Pada generasi F4 terjadi fenomena yang menarik yaitu menurunnya kemampuan ketahanan terhadap temperatur yang dicobakan dan penurunannya sangat tajam mencapai $15,5{ }^{\circ} \mathrm{C}$ dengan kisaran toleransi terhadap temperatur yang juga menurun (Tabel 1). Belum diketahui, terjadinya penurunan ketahanan terhadap temperatur, namun diduga perkawinan antar individu yang masih rentan terhadap temperatur, menurunkan populasi dengan ketahanan terhadap temperatur yang rendah.

Pada generasi F5 terjadi kenaikkan resistensi yang meningkat tajam terhadap rentang temperatur dibandingkan generasi F4, meskipun nilai FC LT ${ }_{50}$ masih selingkup dengan generasi F1, F2 dan F3 (Tabel 1). Masih selingkupnya nilai FC LT $_{50}$ F5 menunjukkan bahwa individu-individu penyusun populasi generasi F5 masih banyak tersusun oleh fenotipe-fenotipe rentan dibandingkan yang resisten. Komposisi populasi ini juga ditunjukkan oleh nilai $\chi^{2}$ hitung yang sangat berbeda nyata dibandingkan dengan nilai $\chi_{0,05}^{2}$. Ketahanan populasi tungau predator Amblyseius sp. terhadap temperatur

Tabel 1. Tingkat resistensi tungau predator Amblyseius sp. terhadap temperatur

\begin{tabular}{ccccc}
\hline Generasi & $\mathrm{LT}_{50}(95 \% \mathrm{FL})\left({ }^{0} \mathrm{C}\right)$ & $\mathrm{RR}$ & Slope $\pm \mathrm{SE}\left({ }^{0} \mathrm{C}\right)$ & $\chi^{2}(\mathrm{df}=18)$ \\
\hline P (parental) & $20,40(19,1-21,6)$ & 1,00 & $8,70 \pm 1,04$ & 12,40 \\
F1 & $20,35(19,1-21,6)$ & 0,99 & $8,40 \pm 1,02$ & 14,08 \\
F2 & $20,35(19,1-21,6)$ & 1,00 & $8,40 \pm 1,02$ & 14,08 \\
F3 & $23,20(21,1-25,3)$ & 1,14 & $4,03 \pm 0,46$ & 30,79 \\
F4 & $15,50(13,8-16,7)$ & 0,67 & $8,93 \pm 1,52$ & 5,09 \\
F5 & $23,90(22,1-25,9)$ & 1,54 & $8,76 \pm 1,01$ & 28,51 \\
F6 & $21,50(20,0-22,9)$ & 0,89 & $7,71 \pm 0,93$ & 9,52 \\
F7 & $29,10(26,4-33,3)$ & 1,35 & $4,51 \pm 0,80$ & 7,68 \\
F8 & $29,90(27,9-32,7)$ & 1,03 & $6,75 \pm 0,97$ & 13,54 \\
\hline
\end{tabular}

LT50 (Lethal Temperature 50), FL (Fiducial Limit), RR (Rasio Resistensi), F1..F8 (Filial 1..Filial 8), $\chi_{0,05}^{2}=9,4$. 
yang ditunjukkan oleh nilai $\mathrm{FC}_{50}$ yang masih selingkup berlangsung hingga generasi F6. Demikian pula dengan nilai $\chi^{2}$ hitung yang sangat berbeda nyata dibandingkan dengan nilai $\chi_{0,05}^{2}$.

Berbeda dengan generasi sebelumnya (P, F1 sampai F6), pada generasi F7 terjadi peningkatan ketahanan terhadap temperatur yang cukup besar. Peningkatan ketahanan terhadap temperatur dapat dilihat dari nilai $\mathrm{FC}^{\mathrm{LT}_{50}}$ generasi $\mathrm{F} 7$ yang tidak lagi selingkup dibandingkan nilai $\mathrm{FC} \mathrm{LT}_{50}$ generasi-generasi sebelumnya. Pada generasi F7 ini, populasi tungau predator Amblyseius sp. resisten pada temperatur $29,1^{\circ} \mathrm{C}$ dengan rentang mencapai 26,4 sampai $33,3{ }^{\circ} \mathrm{C}$. Telah resistennya populasi tungau predator Amblyseius sp. juga ditunjukkan oleh peningkatan rasio resistensi (RR) yang mencapai 1,35 kali dibandingkan generasi induk (P). Berubahnya komposisi individu penyusun populasi melalui mortalitas individu-individu yang rentan terhadap temperatur juga ditunjukkan oleh nilai $\chi^{2}$ hitung yang menjadi berbeda tidak nyata dibandingkan dengan nilai $\chi_{0,05}^{2}$. Homogenitas individu-individu penyusun populasi yang kini tersusun oleh individu-individu yang resisten temperatur juga dapat diketahui dari nilai slope yang memperlihatkan kelandaian garis apabila nilai slope ini diplotkan.

Resistennya populasi tungau predator Amblyseius sp. generasi F7 ternyata bertahan pada generasi F8, meskipun rasio resistensinya tidak meningkat tajam. Diduga, seleksi temperatur terhadap individu-individu dengan fenotipe rentan masih berlangsung meskipun nilai FC LT $_{50}$ generasi F8 selingkup dengan F7. Sudah tidak selingkupnya kisaran temperatur dan meningkatnya ketahanan populasi tungau predator terhadap temperatur menjadi petunjuk telah resistennya populasi Amblyseius sp terhadap kisaran temperatur yang dicobakan (Tabel $1)$.

Lebih resistennya tungau predator Amblyseius sp. hingga temperatur $33,3^{\circ} \mathrm{C}$ ini memberikan harapan akan konservasi pengendalian alamiah tetap tinggi pada kondisi pemanasan global dan perubahan iklim. Xia et al. (2011) dan Budianto \& Munadjat (2012) mengemukakan bahwa lama waktu perkembangan tungau predator famili Phytoseiidae berlangsung lebih cepat satu hari dari 15 hari yang seharusnya apabila dipelihara pada suhu $30{ }^{\circ} \mathrm{C}$. Menurut Xia et al. (2011), pada temperatur $28{ }^{\circ} \mathrm{C}$ laju kenaikkan intrinsik populasi tungau predator famili Phytoseiidae adalah tertinggi dan secara berangsur-angsur mengalami penurunan dengan meningkatnya temperatur sampai $32{ }^{\circ} \mathrm{C}$. Pada temperatur di atas $32{ }^{\circ} \mathrm{C}$ telah menghentikan laju peletakkan telur tungau predator famili Phytoseiidae.

Hasil penelitian ini juga menjawab keraguan pernyataan Perring \& Lackey (1989), Skirvin \& Fenlon (2003), Domingos et al. (2010) yang mengemukakan bahwa tungau predator famili Phytoseiidae baru sebatas potensial sebagai agen pengendali hayati terhadap $T$. urticae pada kondisi pemanasan global dan perubahan iklim. Meskipun demikian, diperlukan penelitian lanjutan mengenai efektivitas predasi tungau predator Amblyseius sp. setelah resisten temperatur untuk mengkonfirmasi pernyataan tetap efektif sebagai agen pengendali hayati tungau hama T. urticae.

Hasil analisis ragam menunjukkan bahwa pemberian tahap perkembangan $T$. urticae sangat mempengaruhi efektivitas kemampuan predasi Amblyseius sp. resisten temperatur $(\mathrm{P}<0,01)$. Hasil uji lanjut menunjukkan bahwa stadium telur $T$. urticae lebih banyak dipilih dan dipredasi oleh tungau predator Amblyseius sp. resisten temperatur (Tabel 2).

Hasil penelitian ini sama dengan hasil penelitian Shipp et al. (2011) yang mengemukakan bahwa tungau predator Amblyseius cucumeris memiliki kemampuan predasi yang tetap tinggi terhadap stadium telur pada percobaan skala laboratorium yang temperaturnya diatur konstan pada $32{ }^{\circ} \mathrm{C}$. Pada temperatur ini, Shipp et al. (2011) melaporkan bahwa laju predasi sama tinggi dengan temperatur $28{ }^{\circ} \mathrm{C}$ sehingga kenaikkan temperatur masih dapat ditoleransinya dalam bentuk predasi stadium telur yang sama besar. Kemungkinan hal ini terjadi selain telur yang tidak mobil, juga kandungan nutriennya yang lebih memenuhi kebutuhan tungau predator. Dengan demikian, pada skala laboratorium

Tabel 2.Kemampuan predasi Amblyseius sp. resisten temperatur yang diberi pakan beberapa tahap perkembangan T. urticae

Tahap perkembangan T. urticae

$\begin{array}{ll}\text { Telur } & 2,29 \pm 0,17 \mathrm{a} \\ \text { Larva } & 2,01 \pm 0,22 \mathrm{~b} \\ \text { Nimfa } & 1,53 \pm 0,20 \mathrm{c} \\ \text { Dewasa } & 1,18 \pm 0,28 \mathrm{c}\end{array}$

Huruf yang berbeda pada kolom yang sama, menunjukkan perbedaan yang nyata menurut uji BNT pada $\alpha=0,05$ 
tungau predator ini memenuhi persyaratan menjadi tungau predator sebagaimana telah dikemukakan oleh Knulle (1991); van Emden (1991); Bakker et al. (1993); Drukker et al. (1997); McMurtry \& Croft (1997); dan McIntyre (1999).

\section{SIMPULAN}

Temperatur mampu menyeleksi individu-individu penyusun populasi tungau predator Amblyseius sp. yang rentan temperatur menjadi populasi yang resisten terhadap temperatur hingga $33,3{ }^{\circ} \mathrm{C}$. Perubahan menjadi populasi tungau predator Amblyseius sp. yang resisten temperatur tidak mengubah efektivitas predasi yang tetap tinggi terhadap stadium telur T. urticae dibandingkan stadium $T$. urticae yang lain.

\section{SANWACANA}

Peneliti mengucapkan terima kasih kepada ketua Lembaga Penelitian dan Pengabdian pada Masyarakat, Universitas Jenderal Soedirman yang telah memberikan kesempatan dan dana untuk melakukan penelitian ini. Terima kasih peneliti sampaikan juga kepada Rektor Universitas Jenderal Soedirman dan Dekan Fakultas Biologi, Universitas Jenderal Soedirman, yang telah memberikan kesempatan melaksanakan penelitian ini sehingga kami mempunyai kesempatan mengekspresikan kemampuan meneliti kami.

\section{DAFTAR PUSTAKA}

Allen CM. 2009. Thermal biology and behaviour of two predatory phytoseiid Mites : Amblyseius swirskii (Athias-Henriot) (Acari : Phytoseiidae) and Phytoseiulus longipes (Evans) (Acari : Phytoseiidae). Thesis Doctor of Phylosophy (Unpublished), School of Biosciences, The University of Birmingham.

Bakker FM. 1994. The Selection of phytoseiid natural enemies for biological control of the cassava green mite. In Selecting Phytoseiid predators for biological control, with emphasis on the significance of tri-tropic interactions. Disertation (Unpublished), University of Amsterdam.

Bakker FM \& Jacas JA. 1995. Pesticides and phytoseiid mites: strategies for risk assessment. Ecotoxicology and Environmental Safety 32:5867.
Bakker FM, Klein ME, Mesa NC, \& Braun AR. 1993. Saturation deficit tolerance spectra of phytophagous mites and their phytoseiid predators on cassava. Exp. and App. Acarology 17:97113.

Budianto BH \& Munadjat A. 2012. Kemampuan reproduksi tungau predator famili phytoseiidae pada berbagai kepadatan Tetranychus urticae dan polen tanaman di sekitar tanaman singkong (Manihot esculenta Crantz). J. HPT Tropika, 12:129-137.

Crooker A. 1985. Embrionic and Juveniel Development of Tetranychus urticae. In Helle W dan Sabelis MW (Eds) Spider Mite : Their Biology Natural Enemies and Control. Elsevier, Netherlands.

Denmark HA \& Muma MH, 1989. A Revision of the Genus Amblyseius Berlese, 1974 (Acari : Phytoseiidae). Occasional Papers of the Florida State Collection of Arthropods, Volume 4. Florida Department of Agriculture and Consumer Services.

Domingos CA, Da S Melo JW, Gondim MG Jr, De Moraes GJ, Hanna R, Lawson-Balagbo LM, \& Schausberger P. 2010. Diet-dependent life history, feeding preference and thermal requirements of the predatory mite Neoseiulus baraki (Acari: Phytoseiidae). Exp. Appl. Acarol. 50:201-15.

Drukker B, Janssen A, Ravensberg W, \& Sabelis MW. 1997. Improved control capacity of the mite predator Phytoseiulus persimilis (Acari: Phytoseiidae) on tomato. Experimental dan Applied Acarology 21:507-518.

Gotoh T, Yamaguchi K, \& Mori K. 2004. Effect of temperature on life history of the predatory mite Amblyseius (Neoseiulus) californicus (Acari: Phytoseiidae). Exp. Appl. Acarol. 32(1-2):15-30.

Hanna R, Onzo A, Lingeman R, Yaninek JS, \& Sabelis MW. 2005. Seasonal cycles and persistence in an acarine predator-prey system on cassava in Africa. Population Ecology 10:1007-1044.

Knulle W. 1991. Life-cycle strategies in unpredictably varying environments : genetic adaptations in a colonizing mite. In Schuster R dan PW Murphy (Ed.) The Acari. Reproduction, development and life-history strategies. pp. 51-56. Chapman dan Hall. 
Lee HS \& Gillespie DR. 2011. Life tables and development of Amblyseius swirskii (Acari: Phytoseiidae) at different temperatures. Exp. Appl. Acarol. 53:17-27.

Luedeling E, Steinmann KP, Zhang MA, Brown PH, Grantz J, \& Girvetz EH. 2011. Climate change effects on walnut pests in California. Global Change Biology 17:228-238.

McIntyre J. 1999. The role of plants in attracting predators and parasitoids to control herbivore feeding, Yahoo.com, 6 pp.

McMurtry JA \& Croft BA. 1997. Life-styles of phytoseiid mites and their role in biological control. Ann. Rev. Entomol. 42:291-321.

Mochizuki M. 1994. Variations in insecticide susceptibility of the predatory mite, Amblyseiuswomersleyi Schicha (Acarina, Phytoseiidae) in the tea fields of Japan. Applied Entomology dan Zoology 29:203-209.

Overmeer WPJ, Doodeman M, \& van Zon AQ. 1982. Copulation and egg production in Amblyseius potentillae and Typhlodromus pyri (Acari, Phytoseiidae). J. App. Entomology 93:1-11.

Perring TM \& Lackey LJ. 1989. Temperature and humidity effects on mortality and pre-adult development of two Phytoseiulus persimilis strains (Acari: Phytoseiidae). International Journal of Acarology. 15( 1): 47 - 52.

Shipp, JL, Ward KI, \& Gillespie TJ. 2011. Influence of temperature and vapor pressure deficit on the rate of predation by the predatory mite, Amblyseius cucumeris, on Frankliniella occidentalis. Entomologia Experimentalis et Applicata 78: 31-38.
Skirvin DJ \& Fenlon JS. 2003. The effect of temperature on the functional response of Phytoseiulus persimilis (Acari: Phytoseiidae). Exp. Appl. Acarol. 31:37-49.

Tian T, Grafton-Cardwell EE, \& Granett J. 1992. Resistance of Tetranychus urticae Koch (Acari: Tetranychidae) to cyhexatin and fenbutatin-oxide in California pears, Econ. Entomol. 85:20882095.

Tsoukanas VI, Papadopoulos GD, Fantinou AA, \& Papadoulis G Th. 2006. Temperature-dependent development and life table of Iphiseius degenerans (Acari: Phytoseiidae). Environ. Entomol. 35:212-218.

Van Emden 1991. Plant diversity and natural enemy efficiency In agroecosystems. In: MacKauer M, LE Ehler \& J Roland (Ed.) Critical Issues in Biological Control, Androver, Hants.

Xia B, Zou Z, Li P, \& Lin P. 2012. Effect of temperature on development and reproduction of Neoseiulus barkeri (Acari: Phytoseiidae) fed on Aleuroglyphus ovatus. Exp. Appl. Acarol. 56: 33-41.

Zundel C, Nagel P, Hanna R, Korner F, \& Schidegger U. 2009. Environment and host-plant genotype effects on the seasonal dynamics of a predatory mite on cassava in sub-humid tropical Africa. Agricultural and Forest Entomology, 2009, DOI : 10.1111, 1461-9563. 